\title{
Pengelolaan Kelas dalam Meningkatkan Motivasi Belajar siswa
}

\author{
Warni Tune Sumar \\ Jurusan Manajemen Pendidikan Fakultas Ilmu Pendidikan \\ Universitas Negeri Gorontalo \\ E-mail: warnisumar@ung.ac.id
}

\section{INFO ARTIKEL}

Sejarah Artikel:

Diterima: Januari 2020

Disetujui: Februari 2020

Dipublikasi: Maret 2020

\section{Kata kunci:}

Mendesain,

Mengorganisasikan,

Monitoring,

Mengevaluasi

Keywords:

Designing, Organizing,

Monitoring, Evaluating

\begin{abstract}
ABSTRAK
Penelitian ini bertujuan untuk mengetahui gambaran yang riil mengenai Pengelolaan Kelas di Sekolah Dasar se Kecamatan Limboto Kabupaten Gorontalo. Metode yang digunakan dalam penelitian adalah deskriptif kuantitatif. Tehnik pengumpulan data yaitu angket, observasi dan dokumen. Hasil penelitian menujukan bahwa Pengelolaan Kelas di Sekolah Dasar se Kecamatan Limboto Kabupaten Gororntalo. Meliputi: (1) Mendesain kelas berada dalam kategori baik. Namun perlu ditingkatkan lagi karena masih sebagaian guru belum mampu mendesain kelas, (2) Mengorganisasikan kelas berada pada kategori baik. Namun perlu ditingkatkan lagi kearah yang lebih baik, sebab sesuai hasil olahan data masih sebagaian besar guru belum mampu mengorganisasikan kelas dalam proses pembelajaran. (3) Monitoring kelas berada dalam kategori baik. Namun perlu ditingkatkan lagi, sebab masih sebagaian guru belum mampu mengontrol kelas dalam kegiatan belajar mengajar, (4) mengevaluasi kelas berada pada ketegori baik. Maka dari itu disarankan untuk kepala sekolah diharapkan lebih ditingkatkan pembinaan dan pengawasan terhadap kinerja guru serta guru diharapkan untuk lebih ditingkatkan lagi kemampuannya dalam pengelolaan kelas.
\end{abstract}

\begin{abstract}
This study aims to find a real picture of Classroom Management in Primary Schools in Limboto District, Gorontalo. Data collection techniques are questionnaires, observations and documents. The results of the study aimed that Classroom Management in Primary Schools in the Limboto District of Gororntalo Regency. Includes: (1) Designing classes are in good category. However, it needs to be improved because some of the teachers have not been able to design the class, (2) Organizing the class is in the good category. However, it needs to be improved in a better direction, because according to the results of the processed data most of the teachers have not been able to organize the class in the learning process. (3) Class monitoring is in the good category. But it needs to be improved again, because some teachers are still not able to control the class in teaching and learning activities, (4) evaluating the class is in the good category. It is therefore recommended for principals to be expected to further enhance their guidance and supervision of teacher performance and teachers are expected to further improve their abilities in classroom management.
\end{abstract}

(C)2020 Warni Tune Sumar Under The License CC BY-SA 4.0 


\section{PENDAHULUAN}

Keberhasilan siswa dalam belajar sangat ditentukan oleh strategi pembelajaran yang dilakukan oleh guru. Guru dituntut untuk memahami komponen-komponen dasar dalam melaksanakan kegiatan pembelajaran di dalam kelas. Oleh karena itu guru dituntut untuk memahami tentang filosofis mengajar dan belajar itu sendiri, mengajar tidak hanya sekedar mentransfer ilmu pengetahuan, akan tetapi juga mengetahui sejumlah perilaku yang akan menjadi kepemilikan siswa. Pendidikan di Indonesia masih rendah, ketinggalan dengan negara tetatangga, ini dikarenakan pengelolaan yang kurang maksimal. Rendahnya mutu dan kualitas pendidikan di Indonesia, hal ini menjadi tangggung jawab bersama untuk memperbaikinya terutama guru. Masalah utama pendidikan di Indonesia hingga saat ini adalah rendahnya mutu pendidikan, khususnya pendidikn dasar dan menengah (Tilaar, 2000).

Guru sebagai orang yang melaksanakan tugas mendidik atau orang yang memberikan pendidikan dan pengajaran baik secara formal maupun non formal (Aziz, 2003:51). Guru merupakan faktor kunci keberhasilan siswa dalam aktivitas mengajar, karena guru berinteraksi langsung dengan siswa dalam proses pembelajaran, sehingga perilaku guru dapat berpengaruh langsung dan ditiru oleh siswa. Kondisi ini sangat dilematis bagi guru, sebab disatu sisi guru sarat dengan tuntutan terhadap peran strategis dalam menciptakan sumber daya manusia (SDM) yang unggul belum terwujud sesuai tuntutan masyarakat sebagai pengguna jasa, sedangkan disisi lain guru yang dihasilkan oleh produsen tunggal yaitu lembaga pendidikan dan tenaga kependidikan (LPTK) belum semuannya matang atau profesionalisme. Hal ini dipertegas oleh Jacobson dalam (Imron, 1996:14) yang menyatakan tidak semua guru lulusan LPTK berada dalam well traned dan wel qulified. Bahkan lebih tegas lagi pernyataan Alder dalam (Imron, 1996:16) bahwa guru adalah orang yang sedang menuju terdidik, dan oleh sebab itu guru hendaknya belajar sambil mengajar.

Menurut UU RI Nomor 20 Tahun 2003 tentang Sistem pendidikan Nasional Bab I pasal (1) dinyatakan bahwa pendidikan adalah usaha mewujudkan suasana belajar dan proses pembelajaran agar peserta didik secara aktif mengembangkan potensi dirinya untuk memiliki kekuatan spritual keagamaan, pengendalian diri kepribadian, kecerdasasan, akhlak mulia serta keterampilan yang diperlukan dirinya, masyarakat, 
bangsa dan negara. Pendidikan adalah usaha sadar dan bertujuan untuk mengembangkan kualitas manusia sebagai suatu kegiatan yang sadar akan tujuan. Aktivitas dalam mendidik yang merupakan suatu pekerjaan memiliki tujuan dan ada sesuatu yang hendak dicapai dalam pekerjaan tersebut maka dalam pelaksanaannya berada dalam suatu proses yang berkesinambungan di setiap jenis dan jenjang pendidikan. Semuanya berkaitan dalam suatu sistem pendidikan yang integral.

Pengaturan metode, strategi dan kelengkapan dalam pengajaran adalah bagian dari kegiatan manajemen pembelajaran yang harus dilakukan oleh guru. Untuk memuwujudkan pengelolaan kelas di sekolah dasar lingkungan fisik yang menguntungkan dan memenuhi syarat akan mendukung meningkatnya intensitas pembelajaran siswa dan mempunyai pengaruh positif terhadap pencapaian tujuan pengajar. Pengelolaan kelas di sekolah dasar tidak hanya pengaturan belajar, fasilitas fisik dan rutinitas tetapi menyiapkan kondisi kelas dan lingkungan sekolah agar terciptanya kenyaman dan suasana belajar yang efektif. Oleh karena itu sekolah dan kelas perlu dikelola secara baik dan menciptakan iklim belajar yang menunjang.

Guru harus memahami beberapa faktor yang dapat mempengaruhi belajar anak, supaya tercipta proses belajar yang baik. Faktor yang perlu diperhatikan antara lain kondisi fisik, sosial emosional dan organisasional. Semua faktor ini harus dipahami oleh guru agar tujuan KBM dapat tercapai dengan sebaik-baiknya, atau setiap kegiatan belajar mengajar, baik yang sifatnya instruksional maupun tujuan pengiring akan dapat dicapai secara optimal. Lingkungan fisik yang memenuhi syarat, mendukung meningkatnya intensitas proses KBM siswa disamping itu juga mempunyai pengaruh tujuan pengajaran.

Setiap proses belajar mengajar kondisi ini harus direncanakan dan diusahakan oleh guru secara sengaja agar dapat dihindarkan kondisi yang dirugikan, dan mengembangkan kepada kondisi yang kondusif. Kondisi fisik di sekolah senatiasa nyaman, antara lain ruang harus diusahakan memenuhi syarat. Ukuran ruangannya harus cukup memberi keluasan bergerak, cahaya dan sirkulasi udara baik dan pengaturan perabot harus tertata rapi agar siswa bergerak bebas. Fungsi pengelolaan kelas sebenarnya merupakan penerapan fungsi-fungsi pengelolaan tersebut harus disesuaikan dengan dasar filosofis dan pendidikan (belajar-mengajar) di dalam kelas. Fungsi-fungsi manajerial yang harus di lakukan guru itu meliputi: merencanakan, mengorganisasikan, 
memimpin, mengendalikan. Namun kenyataan berdasarkan kondisi riil yang ada di lapangan bahwa masih ada beberapa sekolah dasar yang belum memahami tentang tata cara pengelolaan kelas yang baik. Seperti dalam pengaturan ruangan kelas masih ada kelas yang tempat duduknya tidak ditata dengan rapi kemudian jendela dan fentilasi sudah tertutup dengan gorden sehingga cahaya matahari tidak masuk ke dalam kelas dan sirkulasi udara tidak lancar sehingga kelas menjadi pengap dan akibatnya sisw tidak termotivasi untuk belajar sehingga hasil belajar siswa sangat rendah dan salah satu penyebabnya adalah kurang kreatifnya guru dalam mengelolah kelas sehingga pembelajaran hanya terkesan yang penting sudah menyelesaikan tugas mengajar tanpa memperhtikan kemampuan siswa.

Menurut (Syaiful Bahri, 2006:185) masalah pengelolaan kelas bukanlah merupakan tugas yang ringan. Berbagai faktorlah yang menyebabkan kerumitan. Secara umum faktor-faktor dalam pengelolaan kelas dibagi menjadi dua golongan yakni faktor interen dan faktor ekteren. Dalam rangka memperkecil masalah gangguan dalam pengelolaan kelas, memperhatikan prinsip-prinsip pengelolaan kelas yang perlu diperhatikan oleh guru dapat diuraikan sebagai berikut:(1). hangat dan antusias, diperlukan dalam proses belajar mengajar. Guru yang hangat dan akrab dengan siswa selalu menunjukan antusias pada tugasnya pada aktivitasnya dapat berhasil dalam mengimplementasi pengelolaan kelas. (2) tantangan, penggunaan kata-kata, tindakan, cara kerja dapat meningkatkan gairah siswa untuk belajar sehingga mengurangi kemungkinan munculnya tingkah laku yang menyimpang dapat menarik perhatian siswa, dan dapat mengendalikan gairah belajar siswa. (3) bervariasi, penggunaan alat media, gaya mengajar guru, pola interaksi antara guru dan siswa dapat mengurangi munculnya gangguan, meningkatkan perhatian siswa. Apabila penggunaanya bervariasi merupakan kunci tercapainya pengelolaan kelas yang efektif dan menghindari kejenuhan. (4) keluwesan, tingkah laku guru untuk mengubah strategi mengajarnya dapat mencegah kemungkinan munculnya ganguan siswa serta menciptakan iklim belajar mengajar yang efektif. Keluwesan pengajaran dapat mencegah munculnya gangguan seperti keributan siswa, tidak ada perhatian, tidak mengerjakan tugas. (5) penekanan pada Hal-hal yang positif, pada dasarnya dalam mengajar dan mendidik, guru harus menekankan pada hal-hal yang positif dan menghindari pemusatan perhatian siswa pada hal-hal yang negatif. (6) penanaman displin diri, tujuan akhir pengelolaan kelas adalah siswa dapat mengembangkan disiplin diri 
sendiri, guru sebaiknya selalu mendorong siswa untuk melaksanakan disiplin dan guru hendaknya menjadi teladan mengenai pengendalian diri dan pelaksanaan tanggung jawab (Djamarah, 2006:185).

Pengelolaan kelas adalah proses pemberdayaan sumber daya baik material element maupun human element didalam kelas oleh guru sehingga memberikan dukungan terhadap kegiatan belajar siswa dan mengajar guru. Sebagai sebuah proses maka dalam pelaksanaanya pengelolaan kelas memiliki kegiatan-kegiatan yang harus dilakukan guru. Dalam pengelolaan kelas guru melakukan sebuah proses atau tahapan -tahapan kegiatan yang dimulai dari merencanakan, melaksanakan dan mengevaluasi sehingga apa yang dilakukan oleh guru merupakan suatu kesatuan yang utuh dan saling terkait. Pengelolaan kelas adalah suatu usaha yang dilakukan oleh penanggung jawab kegiatan belajar mengajar dengan maksud agar dicapai kondisi yang optimal sehingga dapat terlaksana kegiatan belajar mengajar seperti yang diharapkan (Arikunto, 1986:143). Selain itu bahwa dalam pengelolaan kelas bahwa kegiatan yang dilakukan efektif mengenai sasaran yang hendak dicapai dan efisien tidak menghambur-hamburkan waktu, uang dan sumber daya lainnya titik akhir dari pengelolaan kelas adalah dengan tujuan produktivitas kerja yang tinggi dari siswa. Pengelolaan kelas merupakan ketrampilan seorang guru untuk terciptanyadan memelihara kondisi belajar yang optimal serta mengembalikan kondisi yang sebaik mungkin jika terjadi masalah, baik dengan mendisiplinkan atau melakukan kegiatan remedial terhadap peserta didik di kelas (Hasibuan dan Moejiono, 2006:82)

Pengelolaan kelas tidak bisa dilepaskan dari pengawasan oleh kepala sekolah. Pengawasan seyogyanya dilakukan oleh kepala ekolah secara terus menerus dan berkelanjutan untuk membina dan membimbing guru dalam meninggkatkan kinerja.pengawasan pada hakekatnya adalah memperbaiki hal belajar dan mengajar. Pengawasan/ Supervisi hadir untuk membimbing pertumbuhan kemampuan dan kecakapan professional guru, (Suhardan, 2007:41).

Dalam kehidupan bermasyarakat kita tidak bisa dilepaskan dengan aktivitas pembelajaran. Dengan kata lain kita tidak bisa lepas dengan ruang dan waktu, karena kita tidak bisa terlepas dari kegiatan belajar. Faktor yang mempengaruhi pengelolaan kelas dalam rangka tercapainya tujuan belajar dipengaruhi oleh beberapa faktor diantaranya: Lingkungan fisik, kondisi sosial- emosional dan Kondisi Organisasional. (Sahardan,dkk. 
2008:112-113). Pengelolaan kelas merupakan ketrampilan seorang guru untuk terciptanyadan memelihara kondisi belajar yang optimal serta mengembalikan kondisi yang sebaik mungkin jika terjadi masalah, baik dengan mendisiplinkan atau melakukan kegiatan remedial terhadap peserta didik di kelas (Hasibuan dan Moejiono, 2006:82).

Pengaturan fasilitasi adalah kegiatan yang harus dilakukan siswa, sehingga seluruh siswa dapat terfasilitasi dalam aktivitas di dalam kelas. Pengaturan fisik kelas diarahkan untuk meningkatkan efektivitas belajar siswa sehingga siswa merasa senang, nyaman, aman dan belajar dengan baik.

Untuk lebih jelasnya pengaturan siswa dan fasilitas kelas dapat dilihat dalam bagan seperti dibawah ini:

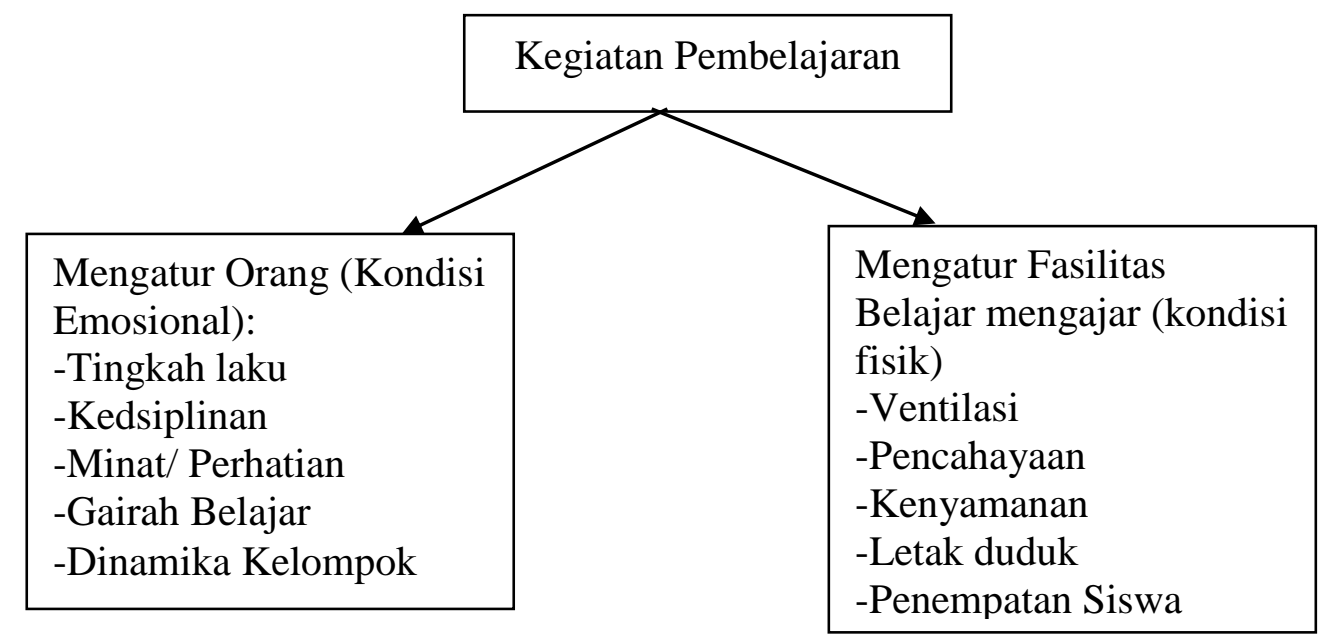

Bagan 1. Kegiatan pembelajaran

Mencermati uraian diatas maka penulis tertarik untuk mengkaji permasalahan dalam suatu penelitian dengan judul "Pengelolaan Kelas di SD Negeri Sekecamatan Limboto Kabupaten Gorontalo:Berdasarkan latar belakang masalah, maka masalah dalam penelitian ini sebagai berikut: (1)Bagaimana mendesain kelas di SD Negeri se kecamatan Limboto, Kabupaten Gorontalo, (2)Bagaimana mengorganisasikan kelas di SD Negeri se kecamatan Limboto, Kabupaten Gorontalo, (3) Bagaimana monitoring kelas di SD Negeri se kecamatan Limboto, Kabupaten Gorontalo (4)Bagaimana mengevaluasi kelas di SD Negeri se kecamatan Limboto, Kabupaten Gorontalo. 


\section{METODE PENELITIAN}

Penelitian ini merupakan penelitian kuntitatif yang bersifat deskriptif. Dalam hal ini peneliti mendeskripsikan fenomena yang berkaitan dengan. Pengelolaan Kelas yang dilakuan pada Sekolah Dasar di Kecamatan Limboto Kabupaten Gorontalo yang beralamat di Jalan Jend. Sudirman No. 123 Limboto. Alasan dipilihnya lokasi tersebut didasarkan atas keingintahuan peneliti tentang pengelolaan Kelas di SD Negeri Kecamatan Limboto Kabupaten Gorontalo

Adapun instrumen pengumpulan data adalah observasi, yaitu melakukan pengamatan terhadap keadaan lokasi penelitian fokus pengamatan yaitu hal-hal yang terkait dengan pengelolaan kelas di Sekolah Dasar Negeri se Kecamatan Limboto Kabupaten Gorontalo: (1) obeservasi, (2) angket. Tehnik analisis data yang digunakan dalam penelitian ini analisis deskriptif persentase dengan analisis statistik deskriptif yaitu analisis data yang menggunkan rumus persentase (\%) dengan mengikuti langkah-langkah sebagai berikut dengan formulasi: $\operatorname{Pr}=\mathrm{F} / \mathrm{N}$ x 100. ( Sugiona 2005: 107) .

\section{HASIL PENELITIAN}

Pengelolaan kelas di SD Negeri se Kecamatan Limboto Kabupaten Gorontalo yang dimaksud dengan penelitian ini adalah menggambarkan kemampuan guru di dalam pengelolaan kelas pada kegiatan belajar mengajar di dalam kelas sementara proses pembelajaran berlangsung yang terkait dengan tugas-tugas dan tanggung jawab yang diembannya dengan indikator yang mencakup: (1) pengelolaan kelas secara fisik, (2) pengelolaan kelas secara non fisik, (3) hambatan-hambatan yang mempengaruhi pengelolaan kelas, (4) usaha-usaha pencegahan dalam pengelolaan kelas.

Sehubungan dengan penelitian dilakukan untuk memperoleh gambaran yang riil tentang pengelolaan kelas di Sekolah Dasar se Kecamatan Limboto Kabupaten Gorontalo yang diuraikan dalam beberapa indikator yaitu:

\section{Mendesain Kelas}

Hasil pengelolaan data untuk indikator pmendesain kelas dalam kegiatan belajar mengajar di Sekolah Dasar se Kecamatan Limboto Kabupaten Gorontalo diperoleh persentase $71,94 \%$ dari frekuensi total angket. 


\section{Menorganisasikan kelas}

Hasil pengelolaan data untuk indikator menorganisasikan kelas dalam kegiatan belajar mengajar di Sekolah Dasar se Kecamatan Limboto Kabupaten Gorontalo diperoleh persentase $70,84 \%$ dari frekuensi total angket.

\section{Monitoring Kelas}

Hasil pengelolaan data untuk indikator menitoring kelas di Sekolah Dasar se Kecamatan Limboto Kabupaten Gorontalo diperoleh persentase 74,38 \% dari frekuensi total angket. Hasil ini dihubungkan dengan kriteria penilaian angket menitoring kelas adalah baik.

4. Mengevaluasi Kelas

Hasil pengelolaan data untuk indikator mengevaluasi kelas di Sekolah Dasar se Kecamatan Limboto Kabupaten Gorontalo diperoleh persentase 61,64 \% dari frekuensi total angket.

\section{PEMBAHASAN}

Pelaksanaan pengelolaan kelas dilakukan dengan metode atau pendekatan pendekatan dan prinsip pengelolaan kelas,sehingga pelaksanaan pengelolaan kelas dapat berjalan dengan lancar. Guru harus mampu menampilkan sikap professional, lewes, bersemangat dan disipiln yang tinggi.

\section{Mendesain Kelas}

Berdasarkan hasil analisis data untuk indikator mendesain kelas dalam kegiatan belajar mengajar di Sekolah Dasar se Kecamatan Limboto Kabupaten Gorontalo diperoleh persentase 71,94\%. Hasil ini hasil ini menunjukkan bahwa indicator mendesain kelas dalam kegiatan belajar mengajar berada pada kategori baik. Aktivitas yang dilakukan guru dalam belajar dan pembelajaran harus dikembangkan sesuai dengan prinsip prinsip belajar (Davies, 1991:32). Guru sebagai orang yang dituakan dan menjadi suri tauladan bagi siswa sehingga guru harus bisa berkomunikasi dengan baik. Dalam pelaksanaan pengelolaan kelas.guru harus dapat mengondisikan kelas dan siswa semaksimal mungkin shingga tercipta suasana kekeluargaan dengan siswa. Ciptakan suasana menyenangkan, aman dan nyaman jangan ada jarak dengan siswa dalam membimbing dan pembinaan. Karena dengan suasana yang demikian proses kegiatan 
pengelolaan kelas dan pembelajaran dapat dilaksanakan. Suasana belajar yang menyenangkan mendorong minat belajar tinggi. Salah satu masalah dalam menciptakan iklim belajar adalah disiplin (Sahertian, 2000: 145-146). Dengan demikian dapat dipahami bahwa pengelolaan kelas dapat memberikan suatu konstribusi di dalam kegiatan belajar mengajar di dalam kelas dalam hal ini guru sudah menujukan hasil kerjanya dalam menciptakan suasana belajar sehingga siswa mendapatkan pelayanan di dalam proses pembelajaran. Namun disisi lain pengelolaan kelas dalam pengelolaan kelas secara fisik perlu untuk lebih ditingkatkan lagi kearah yang lebih baik, karena masih terdapat sekitar 28,06\% guru belum mampu mengelolah kelas secara fisik dalam kegiatan belajar mengajar

\section{Mengorganisasikan Kelas}

Hasil pengelolaan data untuk indikator menorganisasikan kelas dalam kegiatan belajar mengajar di Sekolah Dasar se Kecamatan Limboto Kabupaten Gorontalo diperoleh persentase 70,84\% dari frekuensi total angket. Hasil ini dihubungkan dengan kriteria penilaian angket mengorganisasikan kelas dalam kegiatan belajar mengajar adalah baik. Menurut Sa'ud (2010), ketrampilan guru berhubungan dengan: 1) Ketrampilan yang berhubungan dengan penciptaan dan pemeliharaan kondisi belajar. Kemampuan guru memperbaiki dan mengambil inisatif mengendalikan kondisi pembelajaran sehingga berjalann optimal, efesien dan efektif. 2) ketrampilan berhubungan dengan pengem-bangan belajar yang optimal. Dengan demikian dapat dipahami bahwa pengelolaan kelas dapat memberikan suatu konstribusi di dalam kegiatan belajar mengajar di dalam kelas dalam hal ini guru sudah menujukan hasil kerjanya dalam mengorganisasikan kelas dalam kegiatan belajar mengajar dari aspek kondisi sosioemosional dan prilaku guru dalam menjalin hubungan kerja sama antara guru dan siswa. Namun disisi lain pengelolaan kelas dalam mengorganisasikan kelas dalam kegiatan belajar mengajar perlu untuk lebih ditingkatkan lagi kearah yang lebih baik, karena masih terdapat sekitar 29,16\% guru belum mampu mengelolah kelas secara non fisik dalam kegiatan belajar mengajar.

\section{Monitoring Kelas}

Hasil pengelolaan data untuk indikator menitoring kelas di Sekolah Dasar se Kecamatan Limboto Kabupaten Gorontalo diperoleh persentase 74,38 \% dari frekuensi 
total angket. Hasil ini dihubungkan dengan kriteria penilaian angket menitoring kelas adalah baik. Dengan demikian dapat dipahami bahwa mengontrol kelas dalam kegiatan belajar mengajar dapat mempengaruhi pengelolaan kelas dalam kegiatan belajar mengajar. Pengelolaan kelas adalah suatu usaha yang dilakukan oleh penanggung jawab kegiatan belajar mengajar dengan maksud agar dicapai kondisi yang optimal sehingga dapat terlaksana kegiatan belajar mengajar seperti yang diharapkan (Arikunto, 1986:143). Dalam hal ini guru sudah menujukan hasil kerjanya dalam menitoring kelas dalam kegiatan belajar mengajar yang dapat mempengaruhi proses pembelajaran dikelas. Namun disisi lain hambatan-hambatan yang mempengaruhi pengelolaan kelas masih perlu untuk lebih ditingkatkan lagi kearah yang lebih baik, karena masih terdapat sekitar 25,62\% guru belum mampu mengontrol kelas dalam kegiatan belajar mengajar sehingga pembelajaran dapat efektif.

\section{Mengevaluasi Kelas}

Hasil pengelolaan data untuk indikator mengevaluasi kelas di Sekolah Dasar se Kecamatan Limboto Kabupaten Gorontalo diperoleh persentase 61,64\% dari frekuensi total angket. Hasil ini dihubungkan dengan kriteria penilaian angket mengevaluasi kelas adalah Baik. Dengan demikian dapat dipahami bahwa mengontrol kelas dalam kegiatan belajar mengajar dapat mempengaruhi pengelolaan kelas dalam kegiatan belajar mengajar hal ini guru sudah menujukan hasil kerjanya dalam mengevaluasi kelas dalam kegiatan belajar mengajar yang dapat mempengaruhi proses pembelajaran dikelas. Namun disisi lain hambatan-hambatan yang mempengaruhi pengelolaan kelas masih perlu untuk lebih ditingkatkan lagi kearah yang lebih baik, karena masih terdapat sekitar 38,36\% guru belum mampu mengontrol kelas dalam kegiatan belajar mengajar sehingga pembelajaran dapat efektif.

\section{SIMPULAN}

Berdasarkan hasil penelitian dan pembahasan yang telah dikemukan dapat disimpulkan bahwa pengelolaan kelas di Sekolah Dasar se Kecamatan Limboto Kabupaten Gorontalo berada pada ketegori baik. Perolehan persentase ini merupakan akumulasi dari: Mendesain kelas pada pengelolaan kelas berada kategori baik. Mengorganisasikan kelas pada pengelolaan kelas berada pada kategori baik. Menitoring 
kelas dalam dalam pengelolaan kelas berada pada kategori baik. Mengevaluasi kelas dalam pengelolaan kelas berada pada kategori baik.

\section{REFERENSI}

Arikunto, Suharsimi. 1986. Tentang Pengelolaan Kelas dan siswa sebuah pendekatan evaluative. Jakarta: PT Raja Grafindo Persada.

Aziz. 2003. Anatomi Organisasi dan Kepemimpinan Pendidikan. Bandung: Alfabeta

Davies, RB. 1991. Teacher as Curricullum Evaluators.Sydney: George Allen and Unwin.

Djamarah. 2006. Strategi Belajar Mengajar. Jakarta: Rineka Cipta

Departemen Pendidikan Nasional, 2000, Panduan Manajemen sekolah, Jakarta, Direktorat Pendidikan Dasar dan Menengah.

Hasibuan dan Moejiono. 2006. Proses Belajar Mengajar. Bandung: Remaja Karya.

Mulyasa. 2014. Menejemen Berbasis Sekolah, Konsep Stategi dan Implementasi. Bandung: Remaja Rosda Karya Offset.

Sahardan, dkk. 2008.Manajemen Pendidikan. Bandung: Alfabeta.

Sahertian. 2000. Teknik Dasar dan Konsep Supervisi Pendidikan dalam Rangka Pengembangan Sumber daya Manusia.Jakarta: Renika Cipta.

Syaiful, Bahri, 1994 Prestasi Belajar dan Kompetensi Guru, Usaha Nasional Surabaya.

Sa’ud, Udin Saefudin. 2013. Inovasi Pendidikan. Bandung: Alfabeta.

Tilaar, H.A.R. 2000. Paradigma Baru Pendidikan Nasional. Jakarta: Rineka Cipta 